\title{
The Manifestation of Internal Corporate Social Responsibility on Employee's Behaviour in Small Medium Sized Enterprises
}

\author{
Mei Peng Low \\ Faculty of Accountancy and Management, Universiti Tunku Abdul Rahman \\ Lot PT 21144, Jalan Sungai Long, Bandar Sungai Long, Cheras \\ 43000 Kajang, Selangor, Malaysia \\ Tel: 603-9019-4722Ｅ-mail: lowmp@utar.edu.my
}

Seng Fook Ong

Faculty of Accountancy and Management, Universiti Tunku Abdul Rahman

Lot PT 21144, Jalan Sungai Long, Bandar Sungai Long, Cheras

43000 Kajang, Selangor, Malaysia

Tel: 603-9019-4722Ｅ-mail: ongsengfook@yahoo.com

Received: May 22, 2015 Accepted: June 10, 2015 Published: July 19, 2015

doi:10.5296/jsss.v2i2.7659 URL: http://dx.doi.org/10.5296/jsss.v2i2.7659

\begin{abstract}
Corporate Social Responsibility (CSR) has gained increasing attention and popularity since the last decade. There are many CSR debates arise since then. These debates were shaped by trends and fundamental changes of the political, social, and economic spheres of life. Tracing back, the precursor to CSR was topic of charitable giving, which had been in existence since 1980s. Todate, CSR has evolved to a business concept that had been accepted widely. Business corporations are focusing on CSR due to tremendous pressures from the society. Presently, CSR approach has emerged from focusing on the shareholders to stakeholders due to the acknowledgement of the crucial roles of stakeholders in every organisation. Stakeholder management and CSR is a relational affair. Stakeholder theory involves list of critical stakeholders namely employees, suppliers, customers, media, local communities,
\end{abstract}


NGOs, that could be source of new competitive advantage. This present a research agenda to look into internal CSR practices as to how it manifest among the crucial stakeholders of every organisation, i.e. the employees, on their attitudes and behaviours. As Small Medium Sized Enterprises (SMEs) are gaining its foothold in Malaysia, they also encountered many challenges, one of these is the issue of high employee turnover that lead to substantial costs to the organisations. The findings reveal that internal CSR practices enhanced employee's job satisfaction and also resulted in the reduction of employee's turnover intention. It was interesting to discover that internal CSR practices enhance employee's organisational commitment like job satisfaction, but it failed to reduce employee's turnover intention through enhanced organisation commitment as a result of internal CSR practices. The results also show that perceived ease of movement has an impact on employee's turnover intention.

Keywords: Employees, Internal CSR, Job satisfaction, Organisational commitment, Turnover intention, Perceived ease of movement 


\section{Introduction}

Ever since the interception Corporate Social Responsibility (CSR), it has gained much attention and popularity both in the business world and the academic research. In line with globalisation, the business environment is becoming more competitive and business corporations are compelled to be innovative enough to create a competitive strategy that able to differentiate their business with others; and one of them is to be involved in CSR activities (Rahim, Jalaludin, \& Tajuddin, 2011). Despite research on CSR has spanned across a few decades in various fields, yet only a handful of academic studies have investigated the relationship between CSR and the commonly neglected stakeholder - the employees. Employees are an essential part of every organisation and they are highly influenced by the CSR initiatives carried out by the organisation. On the other note, CSR in the past was widely concerned by multinational corporations has now being extended to small and medium partnerships as well as sole proprietor (Kucukusta, Mak, \& Chan, 2013). Hence, this open up an avenue of research to investigate the impact of internal CSR practices towards employees in the smaller organisations, such as Small Medium sized Enterprises (SMEs). Meanwhile, the global economy growth is not optimistic as reported by World Bank 2015, it will be of interest to capture the economy outlook in employee's turnover intention. This research paper aims to look into the impact of internal CSR practices among the SMEs in the Klang Valley, Malaysia and its implications towards employee's job satisfaction and organisational commitment with its consequences of turnover intention as well as the moderation effect of perceived ease of movement.

\section{Research Objectives}

According to Morrow (2010), it is surprising to note that little research is conducted on how organisations can developed better workforce by implementing CSR although it may support that CSR will lead to higher job satisfaction and organisational commitment. This is consistent with Ali, Rehman, Yusof (2010) research findings which pointed out that CSR on employees well-being is still at its infancy stage. Kucukusta, Mak and Chan (2013) added that past research on CSR was widely concerned by multinational corporations and now being extended to small and medium partnerships together with sole proprietors. It uncovers an opportunity to investigate CSR practice in SMEs due to its' significant differences from large organisations in the aspects of unique resources and management (Lepoutre \& Heena, 2006). It will be interesting to look into how internal CSR manifest in employee's attitudes and behaviour in SMEs. During the investigation and discussion of employee's turnover intention, the market condition shall be incorporated in order to have a meaningful understanding of the holistic effects.

This research paper has three folds, firstly, the researcher would like to investigate the relationship between internal CSR practices towards employee's job satisfaction and organisational commitment; and secondly, to look into the consequences of job satisfaction and organisational commitment towards employee's turnover intention as the chain consequences from the internal CSR practices. Thirdly, the researcher will look into how perceived ease of movement affect employee's turnover intention. 


\section{Literature Review}

\subsection{Recent Developments of SMEs}

There has been an increased interest in studies of SMEs in the academia and research. The main motivation for this emerging interest is due to its significant contribution in national Gross Domestic Product (GDP) and its role in national economic. SMEs make momentous contribution to the economies of both developed and developing nations in terms of employment generation and development impacts. Overall, SMEs are known to constitute more than $90 \%$ of business worldwide and account for between $50 \%$ and $60 \%$ of employment and more than half of the country's GDP (Inyang, Awa, \& Enuoh, 2013). The similar contribution by SMEs is observed in Malaysia as well. In Malaysia, SMEs businesses are regarded as legally structured entities registered either under the Registration of Businesses Act 1956 (Act 197) or Companies Act 1965 (Act 125). Adding on, the data compiled by the Department of Statistics, Malaysia showed that GDP growth of SMEs in Malaysia had outpaced the overall GDP growth since 2008. SMEs contribution to GDP had risen substantially thereon, e.g. rose from $29.4 \%$ in 2005 to $31.4 \%$ in 2008 .

\subsection{CSR and Employee}

The concept of CSR already longed on the Organisation for Economic Cooperation and Development's agenda through its guidelines for Multinational Enterprises, since 1976 and subsequently revised in 2000. These guidelines are commonly regarded as a benchmark for CSR (Clarke, 2007). Generally, CSR is defined as corporate behaviors which aim to affect stakeholders positively and go beyond its economic interest. Needless to say, CSR has brought about many improvements to the business world, especially in the work place (Al-bdour, Ellisha, \& Lin, 2010). It is reasonable to say that CSR is cross-disciplinary nature (Lockett, Moon, \& Visser, 2006). In fact, Lozano and Prandi (2005) pointed that increasing number of organisations are linking human rights to their CSR strategy screening which acts as policy and a resource for CSR measure and evaluation that are regarded as practices. Clearly, CSR has potential relevance for employee management (Brammer, Millington \& Rayton, 2007), organisational behaviour and human resource management researchers have under investigated CSR (Aguilera, Rupp, Williams, \& Ganapathi, 2007; Rupp, Gananpathy, Aguilera, \& Williams, 2006). More recently, rising interest is on the internal stakeholders, specifically the employees, through the field of organisational behaviour and human resource management (Aguinis \& Glavas, 2013). This development brings to the focus of CSR and employees. There are different terms used in the past research on employee centered CSR, such as secondary stakeholders (Freeman, 1999; Clarkson, 1995); external and internal stakeholders (Verdeyen \& Buggenhout, 2004); contracting and public stakeholders (Charkham, 1994); voluntary and involuntary stakeholders (Clarkson, 1994); internal, external, and societal stakeholders (Werther \& Chandler, 2006); primary social, secondary social, primary non-social, and secondary non-social stakeholders (Wheeler \& Sillanpaa, 1997). Recent research by Thauer (2013), discovered that the motivation for organisation to incorporate CSR practices in human resource practices is due to internal human resource dilemma concerning the human right. Hence, he uses the term labour related CSR. These 
shown that the terms used slightly varied according to the situations of which the stakeholders are involved. Despite the different terms used, the reason for CSR in gaining its important is due to the fact that it is related to the well-being of all stakeholders in the organisation and most importantly, it has gained a foothold within the organisation itself, specifically in the area of human resources (Fuentes-García, Núñez-Tabales, \& Veroz-Herradón, 2008). It also involves social responsibility practices for employees especially in the area of their safety, health and well-being, training and participation in the business, equality of opportunities and work-family relationship (Vives, 2006). With these, the term Internal CSR is adopted in present research as it is comparing with the well-established research on external CSR and the counterpart which has been under investigated is the internal aspect. Internal CSR practices refer to CSR practices which are directly related with the physical and psychological working environment of employees (Turker, 2009). It is expressed in concern for the health and well-being of employees, their training and participation in the business, equality of opportunities, work-family relationship (Vives, 2006).

\subsection{Organisational Commitment}

Organisational commitment is the psychological attachment individuals feel for the organisation (O'Reilly \& Chatman, 1986). Studies have also shown that the CSR practices of an organisation would have a significant positive influence on its employee's organisational commitment (Brammer, Millington, \& Rayton, 2007). Whitener (2001) added on with his conception of the effect of 'high commitment' human resource practices on organisational commitment. As the present research relates internal CSR practice of SMEs, i.e., aspects pertaining to the psychology and physiology of employee, organisational commitment is a relevant construct to be adopted. Allen and Meyer (1996) defined organisational commitment as a psychological link between the employee and his or her organisation that makes it less likely that the employee will voluntarily leave the organisation. In the organisational context, there are three commonly recognized types of organisational commitment, namely affective commitment, continuance commitment and normative commitment. Affective commitment is emotional commitment, i.e., employees stay at their job because they want to stay. Employees with strong affective commitment remain because they want to, and those with strong continuance commitment because they need to, and those with strong normative commitment because they feel they ought to do so. Accordingly, employees with high level of affective commitment will stay because of strong emotional attachment to the organisation. The present research adopts Allen and Meyer (1990)'s model on organisational commitment, employing only one dimension, which is affective commitment, as it matches with the research objective, to gain insight of internal CSR practices in SMEs on employee's attitudes and behaviour. Affective commitment measures employee's identification with the organisation and continuity to stay in the organisation which facilitates their intention to stay or leave the organisation. Affective commitment is more appropriate in present research as compared to normative commitment and continuance commitment to gauge an employee's level of organisational commitment through internal CSR practices. Indeed, organisational variables, rather than employee characteristics, would be better predictor of organisational 
commitment, and it is the 'employee-focused' organisational factors that fulfil the objective of present research.

\subsection{Job Satisfaction}

Job satisfaction is a pleasurable or positive emotional state resulting from the appraisal of one's job. It is the most used research definition of job satisfaction is by Locke (1976), who defined it as a pleasurable or positive emotional state resulting from the appraisal of one's job or job experiences. The implicit understanding of Locke's definition is the importance of both affect, or feeling, and cognition, or thinking. With reference to Social Exchange Theory, job satisfaction can be inferred through the reciprocity between employee and the organisation who he or she attached to. Social Exchange Theory argues that an employee views pleasant working conditions as a 'gift' from the organisation and responds with a 'gift' of increased effort, even if effort is not directly rewarded by monetary incentive scheme. Job satisfaction promotes organisational citizenship behaviour (Organ, 1988), where an employee goes above and beyond the formal requirements of the job and internalizes the organisation's objective function as his or her own. This shown that job satisfaction benefits in ways of increasing intrinsic motivation and organisational commitment. As such, organisational commitment and job satisfaction are being used to measure employee's attitude and behaviour in present study.

\subsection{Turnover Intention}

Generally, there are two major types of turnover; voluntary and involuntary (Price \& Mueller, 1986). Voluntary turnover occurs when the employee quits; and involuntary turnover occurs when the employee is forced to leave. Voluntary turnover is usually the most common, most costly and harmful to an organisation, and most avoidable (Price, 1977). Turnover intention usually occurs prior to voluntary turnover.Turnover intention is the cognitive process of thinking of quitting, planning on leaving, and the desire to leave the job; it is the strongest predictor of voluntary turnover (Mor Barak, Nissly, \& Levin, 2001; Kiyak, Namazi, \& Kahana, 1997; Mobley, Griffeth, Hand, \& Meglino, 1979). Turnover intention is measured in present research to examine whether the presence of internal CSR in SMEs reduce employee's turnover intention.

\subsection{Perceived Ease of Movement}

There is little doubt that labour market conditions affect turnover, but it may be more of a direct effect, which is the labor market acting directly through a psychological process as anticipated acted directly on the behavior itself. If an employee intends to leave a job, he or she most likely would quit when another job became available. The availability of another job controls the behaviour in concert with intention, but not through intention. An employee might well intend to leave as soon as another job has been offered, rather than when he or she believed one could be found. It is clear that when the economy condition is optimistic; when the job market is good, opportunities to find alternative employment are plentiful and turnover is more likely. According to report by World Bank 2015 that the global economy is expanding on an uneven pace due to the prolonged recovery process from global financial crisis. Global recovery was hampered by some new challenges, including a number of 
unexpected shocks, such as the heightened geopolitical conflicts in various areas of the world. As such, it is expected that the growth of world gross product (WGP) is slower in 2015. Fair to note that the economy outlook will certainly have impact on the labour market. Muchinsky and Morrow (1980) once argued that when the Economic Opportunity valve is 'open' which signifies the availability of employment opportunity, the relation between individual factors and turnover will be stronger than when the valve is closed. In fact, many turnover theorists have pointed out that the perception that alternative jobs exist is an important precursor of turnover (e.g., Hulin, Roznowski, \& Hachiya, 1985; March \& Simon, 1958; Mobley, 1977). Evidence suggests a main effect for general labour market conditions in both the economic and psychological literatures. The hypothesized interaction between individual factors such as job satisfaction and general labour market conditions in the psychological literature has also received tentative empirical support. However, the evidence on the role of perceived ease of movement maybe ambiguous as not many studies has included measures of both general labor market conditions and perceived ease of movement. Nevertheless, it is undoubtful that there is interaction between general labour market conditions and intention in influencing turnover. As such, this research paper also aims to look into the effect of perceived ease of movement on employee's turnover intention.

\section{Research Model and Hypotheses}

The discussion above legitimizes a research agenda on investigating the practice of internal CSR in SMEs, particularly on the employee's attitudes and behaviour. The present research aims to uncover the effects of the implementation of internal CSR on employee's organisational commitment and job satisfaction which influence their turnover intention. Perceived ease of movement is also being examined on its possible impact on employee's turnover intention. The research model for current research is shown in Figure 1.

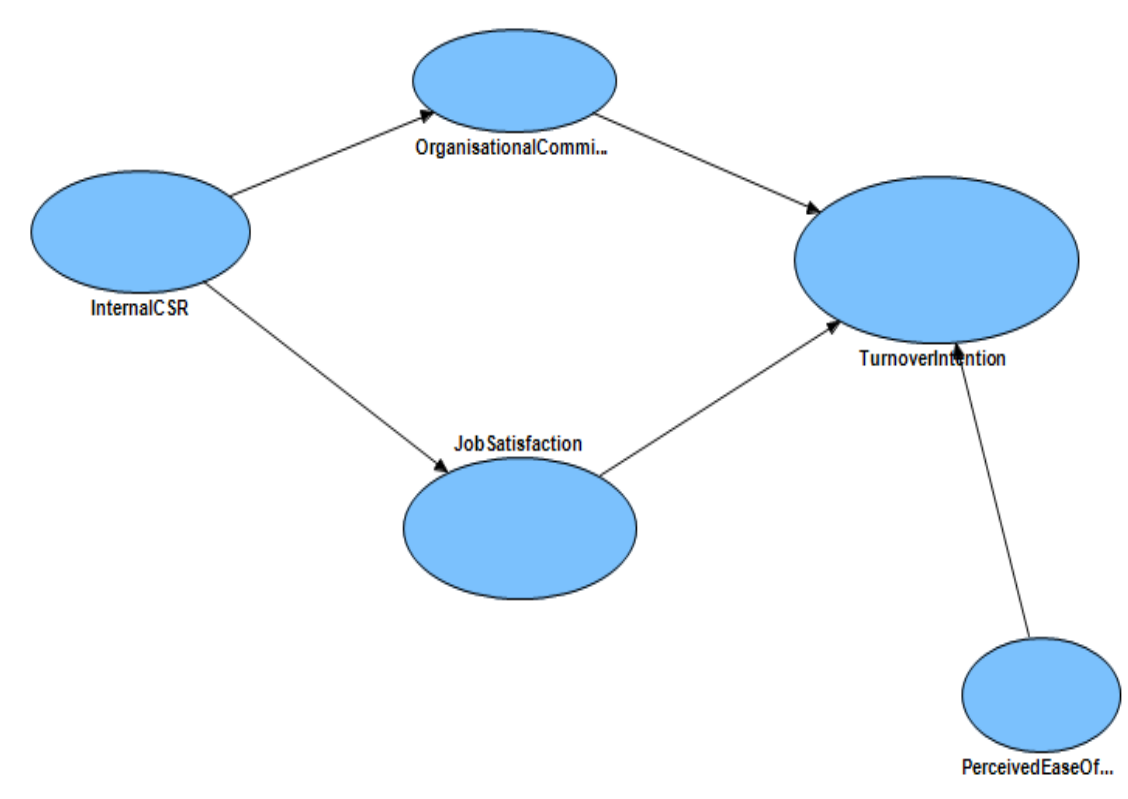

Figure 1. Research model 
Based on the above discussed literatures and research model, the following hypotheses are formulated to carry out the present research:

H1: There is a positive relationship between internal CSR practices and organisational commitment.

$\mathrm{H} 2$ : There is a positive relationship between internal CSR practices and job satisfaction.

H3: There is a negative relationship between organisational commitment and turnover intention.

H4: There is a negative relationship between job satisfaction and turnover intention.

H5: There is a positive relationship between perceived ease of movement and turnover intention.

\section{Research Methodology}

Quantitative approach using structured self-administered questionnaire was adopted in this research. The research respondents are the full time employees who are employed in SMEs located in Klang Valley, Malaysia. Questionnaire is used as a survey tool to collect data based on the present research objectives. Sekaran (2000) mentioned that quantitative method is a method of measurement where data in terms of frequencies, or mean and standard deviations which becomes essential for descriptive studies. Creswell (2002) added that quantitative method is appropriate to measures attitudes and behaviour. Creswell (2002) explained that the advantage of quantitative method is that it allow measurement of perceptions, reactions and attitudes of a sample through a set of structured questions. This main advantage enables comparisons and statistical aggregation of data (Sekaran, 2000). Besides, analysis obtained from quantitative method help to increase objectivity in interpreting data, measures of validity and reliability, which could be easily communicable to others (Byrne, 2002).

The present research employed multi-stage sampling, whereby the first stage is to locate the highest number of SMEs establishments in Malaysia and followed by the second stage of selecting the sample. According to the Department of Statistics, Malaysia, about $35 \%$ of Malaysia SMEs establishments are located in Klang Valley. Hence, the present research frame is set in Klang Valley and followed by convenience sampling randomly selected the directory of firms in Klang Valley. According to Bryman (2012), convenience samples are very common and more prominent in the field of organisation studies. It was also mentioned that social research is frequently based on convenience sampling. Convenience sampling method is used in current research because its virtue of accessibility to the SMEs in Klang Valley. Besides, convenience sampling is suitable in the present research as it provide a springboard for further research and allows possible links to be forged with existing findings in the area of internal CSR practices in Klang Valley, Malaysia.

Pilot study or pre-test of questionnaire is a crucial step in quantitative method to discover any problems either in the instruction or in the questions. A brief pilot study is an excellent way to determine the feasibility of a research. A pilot testing was conducted prior to the full testing 
to ensure the usability of the questionnaire survey. Minor amendments such as rewordings were done to ensure the understandability of the questionnaires before sending out the questionnaire to the target respondents.

\section{Data Analysis}

\subsection{Respondents Profile}

A total of 600 questionnaires were sent out to the employees working in SMEs located in Klang Valley in the month of December 2014. A total of 364 useable responses were received at the end of the data collection process, which constitute to $60.7 \%$. The respondents' profiles are analysed according to the age, gender, education level and managerial role. Majority of the respondents are Chinese, male and less than 30 year old. In term of education level, $48.1 \%$ of the respondents are degree holders. Respondents that participated in the research are mostly not holding any managerial position and do not involved in the decision making of the organisations.

Table 1. Respondents' Profile

\begin{tabular}{llll}
\hline Profile & Description & No. of respondents & Percentage (\%) \\
\hline Age & $<30$ & 245 & $67.3 \%$ \\
& $30-39$ & 81 & $22.3 \%$ \\
& $40-49$ & 28 & $7.7 \%$ \\
Gender & $50-59$ & 9 & $2.5 \%$ \\
& 59 above & 1 & $0.3 \%$ \\
Ethnicity & Male & 205 & $56.3 \%$ \\
& Female & 159 & $43.7 \%$ \\
& Malays & 85 & $23.4 \%$ \\
Education & Chinese & 223 & $61.3 \%$ \\
& Indian & 51 & $14.0 \%$ \\
& Others & 5 & $1.4 \%$ \\
PPM & 68 & $18.7 \%$ \\
& Diploma & 81 & $22.3 \%$ \\
Total & Degree & 175 & $48.1 \%$ \\
\hline
\end{tabular}

\subsection{Results}

Partial Least Square (PLS) method was used to analyse data collected. The rational for employing this technique is its ability to handle theory confirmation and theory development 
as pointed out by Chin (1998). The nature of present research is to confirm the impact of internal CSR practices among the employees and to develop the possible theory to relate to the implementation of internal CSR towards employee's organisation commitment and job satisfaction. In addition, Anderson and Gerbing (1998) explained that PLS can be applied to complex structural equation models with large number of constructs, as the present research consist of large number of constructs in organisation commitment and job satisfaction.

PLS also places minimal restrictions on distributional characteristics and sample size which suit the nature of the present research data distribution and size. The present research followed Anderson and Gerbing (1998) approach in using the Smart PLS M2 Version that employed two-steps analysis approach. According to some studies (Chin, 1998; Gil-Garcia, 2008), bootstrapping method (600 resample) was also carried out to determine the significance levels for the loadings, weights and path coefficients. Figure 1 shows the research model for present research.

\subsection{Measurement Model}

The measurement model in current research was undergo a convergent validity test whereby convergent validity is the degree to which the multiple items that are used to measure the same concept are in agreement. According to Hair, Black, Babin and Anderson (2010), factor loadings, composite reliability and average variance extracted are the key indicators to assess convergent validity. Chin, Gopal and Salisbury (1997) recommended that the loadings of all items shall exceed the value of 0.6. The results shown in Table 1 reveal that the degree to which the construct indicators indicate the latent constructs are ranging between 0.6758 to 0.9474, which within the range of the recommended value of 0.7 (Hair et al., 2010). The average variance extracted which reflects the overall amount of variance in the indicators accounted for by the latent constructs, are ranging between 0.6061 to 0.8546 , which exceeded the recommended value of 0.5 (Hair et al., 2010). The values of Composite Reliability (CR) and Cronbach Alpha are more than 0.7, which often being taken to indicate good reliability of internal consistency. Hence, the results of convergent validity for present study is depict in Table 2. 


\section{Macrothink}

Table 2. Factor loadings and reliability

\begin{tabular}{lllll}
\hline Items & Loadings & CR & AVE & Cronbach Alpha \\
\hline InCSRq1 & 0.6758 & 0.9059 & 0.6601 & 0.8698 \\
InCSRq2 & 0.8629 & & & \\
InCSRq3 & 0.8731 & & & \\
InCSRq4 & 0.8422 & & & \\
InCSRq5 & 0.7920 & & 0.8304 & 0.8979 \\
JSq1 & 0.9233 & 0.9363 & & \\
JSq2 & 0.9045 & & & \\
JSq4 & 0.9058 & & 0.6489 & 0.8656 \\
OCq1 & 0.8480 & 0.9018 & & \\
OCq2 & 0.8310 & & & \\
OCq3 & 0.8220 & & & \\
OCq4 & 0.6794 & & & \\
OCq7 & 0.8352 & & & \\
PEMq1 & 0.9474 & 0.9463 & 0.8546 & \\
PEMq2 & 0.9121 & & & \\
PEMq3 & 0.9134 & & & \\
TIq1 & 0.9330 & 0.9202 & 0.7937 & \\
TIq2 & 0.8827 & & & \\
TIq4 & 0.8553 & & & \\
\hline
\end{tabular}

Discriminant validity is the extent to which the measures do not reflect other variables and it is indicated by low correlations between the measure of interest and the measures of other constructs (Cheung \& Lee, 2010). Adding on, Fornell and Lacker (1981) pointed out that discriminant validity is examined by comparing the squared correlations between the constructs and the variance extracted for a construct. Table 3 reveals that the squares correlation for each constructs is less than the square root of the average variance extracted by the indicators that measured the construct, demonstrating adequate discriminant validity. In total, the measurement model demonstrated adequate convergent and discriminant validity. 
Table 3. Inter-construct correlation

\begin{tabular}{lllll}
\hline Internal CSR & $\begin{array}{l}\text { Job } \\
\text { satisfaction }\end{array}$ & $\begin{array}{l}\text { Org } \\
\text { Commitment }\end{array}$ & $\begin{array}{l}\text { Perceived Ease Of } \\
\text { Movement }\end{array}$ & $\begin{array}{l}\text { Turnover } \\
\text { Intention }\end{array}$ \\
\hline 1 & & & & \\
0.5806 & 0.8124 & & & \\
0.5674 & 0.7775 & 0.8055 & & \\
0.1479 & 0.1425 & 0.1499 & 0.9245 & \\
-0.2549 & -0.4531 & -0.3431 & 0.04232 & 0.9332 \\
\hline
\end{tabular}

Note: Diagonal elements are the square root of the AVE of the reflective scales while off diagonals are the squared correlations between constructs.

\subsection{Structural Model}

A structural model depicts the causal relationship among the constructs in a research model (Sang, Lee \& Lee, 2010), that includes the estimates of the path coefficients and the $\mathrm{R}^{2}$ value, which determine the predictive power of the said model. Both $\mathrm{R}^{2}$ and path coefficients represented by loadings and significance indicate how well the data support the hypotheses posited (Chin, 1998; Sang, et al, 2010). Figure 2 and Table 3 display the results of the structural model from PLS output. Implementation of internal CSR practice $(\beta=0.567, p<$ 0.05 ) explains $32.2 \%$ of the employee's organisation commitment in SMEs which $\mathrm{H} 1$ is supported. Implementation of internal CSR $(\beta=0.581, p<0.05)$ explains $33.7 \%$ of employee's job satisfaction in the SMEs, which $\mathrm{H} 2$ is supported. Organisation commitment $(\beta=0.013, p>0.05)$ is not a significant predicator for employee's turnover intention, thus $\mathrm{H} 3$ is not supported. Job satisfaction $(\beta=-0.478, p<0.05)$ explains $21.7 \%$ of the employee's turnover intention, which H4 is supported. Perceived ease of movement $(\beta=0.109, p>0.05)$ moderate employee's turnover intention, thus H5 is supported. 


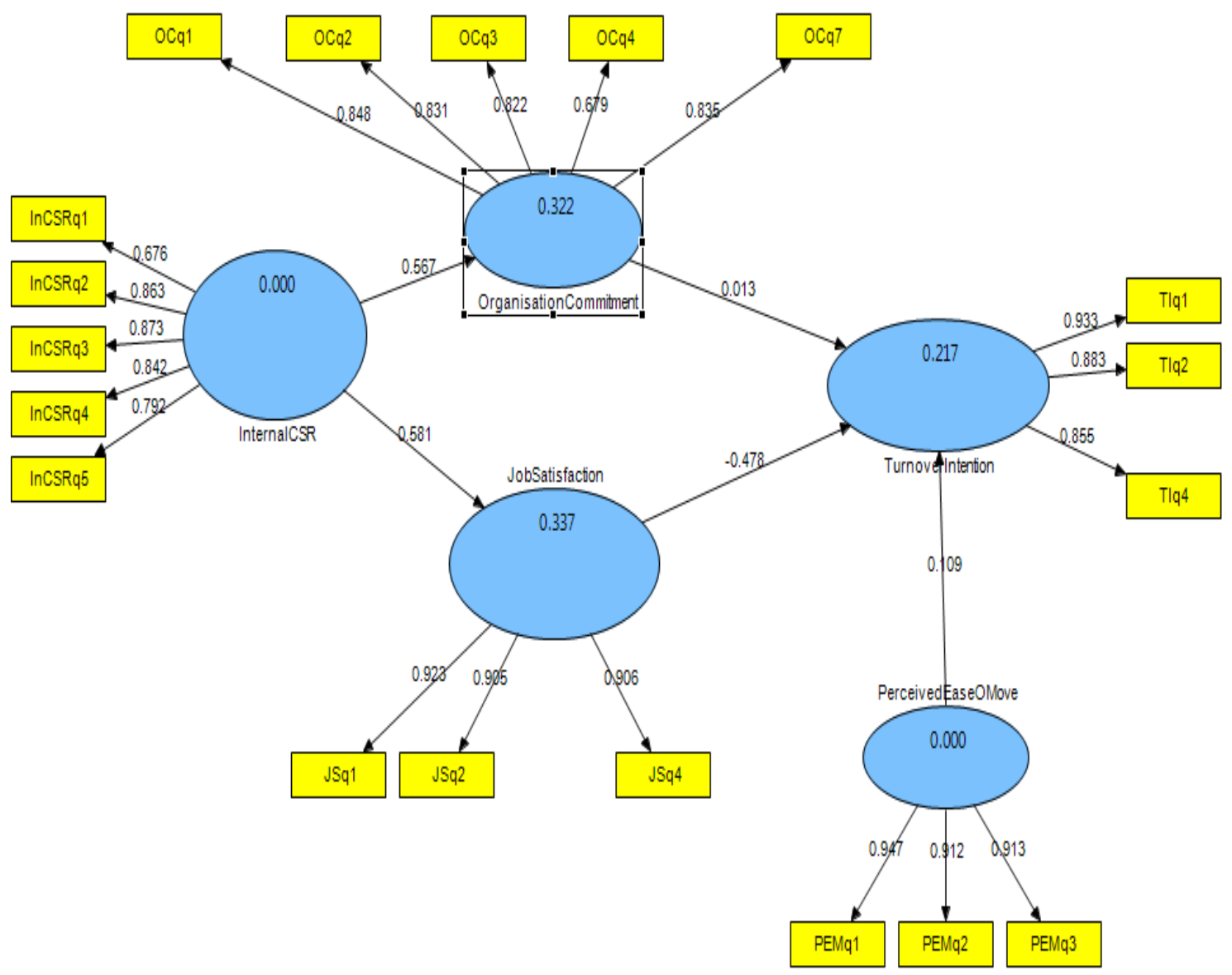

Figure 2. Structural model

Table 4. Summary of structural model

\begin{tabular}{lllll}
\hline Path Description & Hypothesis & $\begin{array}{l}\text { Path } \\
\text { Coefficient }\end{array}$ & $\begin{array}{l}\boldsymbol{t} \\
\text { value }\end{array}$ & Results \\
\hline Internal CSR -> Job Satisfaction & $\mathrm{H} 1$ & 0.581 & 6.6791 & supported \\
Internal CSR -> Organisation Commitment & $\mathrm{H} 2$ & 0.567 & 6.3025 & supported \\
Job Satisfaction -> Turnover Intention & $\mathrm{H} 3$ & -0.478 & 3.0939 & supported \\
Organisation Commitment -> Turnover Intention & $\mathrm{H} 4$ & 0.013 & 0.0802 & not \\
Perceived Ease Of Movement -> Turnover Intention & $\mathrm{H} 5$ & 0.109 & 0.9152 & supported \\
\hline
\end{tabular}

\section{Conclusion and Discussion}

The results reveal that internal CSR practices has a positive relationship on employee's job satisfaction and organisation commitment. The results clearly shown the positive impact of the implementation of internal CSR practices that have enhanced employee's job satisfaction and organisational commitment which are consistent with the Social Exchange Theory (Blau, 1964). Gouldner (1960) further explained the reciprocity of the relationship between 
organisation and its employees, whereby the reciprocity of the relationship explains that there is a positive relationship observed between implementation of internal CSR practices and job satisfaction as well as organisational commitment among the employees. Employees value beneficial treatment through internal CSR practices, while employers seek loyalty and dedication in their work performance (Coyle-Shapiro \& Shore, 2007). The notion of reciprocity expands to enhance employee's job satisfaction, and in turn reduces their turnover intention. However, there is insignificant result obtained in the relationship between organisational commitment and turnover intention. As the present research only captured affective commitment to measure employee's organisation commitment as the consequences of internal CSR practices, which mean employees with high level of affective commitment will stay because of strong emotional attachment to the organisation. The results obtained from present research has dispersed from Allen and Meyer (1990) findings that there is a link between employee and organisation through organisational commitment which decreases the likelihood of eemployee's turnover intention. The rational of the findings could be the respondents participated in the present research are below the age of 30, which they are still searching for their best suited career. Therefore, the results obtained shown that despite internal CSR practices could enhance organisation commitment, but it is not good enough to retain the employees from leaving the organisation. Another possible explanation of the findings is that there is other possible factor which is not measured in present research such as job characteristics that account for the turnover intention as highlighted by Williams and Hazer (1986). As expected, labor market conditions affect turnover directly. The results shown that perceived ease of movement impacted employee's turnover intention, i.e., an employee might well intend to leave as soon as another job has been offered, rather than when he or she believed one could be found. Therefore, this explain that when the perceived ease of movement is high, the employee's turnover intention is enhanced.

\section{Contributions, Limitations and Future Research}

The present research makes several contributions. Firstly, internal CSR practices do has impact on employee's job satisfaction and organisation commitment, which confirms with Social Exchange Theory. Secondly, the current research reveals that there could be other possible factors that affect the relationship between organisation commitment and turnover intention as the consequences of internal CSR practices. This is an unexpected findings uncover in the research which would be further investigated in future research. Future research may also be conducted to capture the possible effect of the age of the respondents in the relationship between organisation commitment, particularly affective commitment and turnover intention. The third contribution is the role played by perceived ease of movement which scant research is done in the aspect of employee's turnover intention. The present research results conform to the expectation that perceived ease of movement will moderate employee's turnover intention.

Despite the contributions made, there are several limitations to this research. Firstly, as the unit of analysis is the employee, hence, the sample size should be larger. Secondly, as the present research discuss on the implementation of internal CSR which focuses on employee's well-being, future research might be conducted by solely on the service sector, instead of all 
the sectors. It will be interesting to make a comparison study between the SMEs with and without internal CSR practices.

In a nutshell, the present research provides insights to the SMEs owners/managers that internal CSR practices could enhance employee's attitudes and behaviours. This findings offer some suggestions to SMEs owners/ managers of the manifestation of internal CSR practices in their organisations which could be a competitive advantage to them to sustain in the present competitive environment.

\section{References}

Aguinis, H., \& Glavas, A. (2013). What corporate environmental sustainability can do for industrial-organizational psychology. In A. H. Huffman \& S. R. Kelin (Eds.), Green organizations: Driving change with I-O psychology (pp. 379-392). New York: Routlege. http://dx.doi.org/10.1111/iops.12059

Aguilera, R., Ruth, V., Rupp, D., Williams, C., \& Ganapathi, J. (2007). Putting the S back in Corporate Social Responsibility: A multi-level theory of social change in organizations. Academy of management Review, 836-863. http://dx.doi.org/10.5465/AMR.2007.25275678

Anderson, J. C., \& Gerbing, D. W. (1998) Structural equation modeling in practice; A review and recommended two-step approach. Psycho Bulletin, 103(3), 411-423. http://dx.doi.org/10.1037/0033-2909.103.3.411

Allen, N. J., \& Meyer, J. P. (1990). The measurement and antecedents of affective, continuance and normative commitment to the organization. Journal of Occupational Psychology, 63, 1-18. http://dx.doi.org/10.1111/j.2044-8325.1990.tb00506.x

Ali, I., Rehman, K. U., Ali, S.I., Yousof, J., \& Zia, M. (2010). Corporate Social Responsibility Influences, employee commitment and organizational performance. African Journal of Business Management, 4(12), 2796-2801.

Al-bdour, A. A., Nasruddin, E., \& Lin, S. K. (2010). The relationship between internal corporate social responsibility and organizational commitment within the banking sector in Jordan. International Journal of Human Social Sciences, 14(6), 932-951.

Blau, P. M. (1964). Exchange and power in social life. New York: Wiley.

Brammer, S., Millington, A., \& Rayton, B. (2007). The contribution of corporate social responsibility to organization commitment. International Journal of Human Resource Management, 18(10), 1701-1719. http://dx.doi.org/10.1080/09585190701570866

Byrne, D. (2002). Interpreting Quantitative Data. London: Sage.

Chin, W. W. (1998). Issues and opinion on structural equation modeling. MIS, Q22(1), 7-16.

Chin, W. W. (2000) Partial least squares for researchers: An overview and presentation of recent advances using PLS approach. 
Chin, W. W., Gopal, A., \& Salisbury, W. D. (1997). Advancing the theory of adoptive structuration: the development of a scale to measure faithfulness of appropriation. Infor Sys Res, 8(4), 342-367. http://dx.doi.org/10.1287/isre.8.4.342

Charkham, J. (1994). Keeping Good Company: A Study of Corporate Governance in Five Countries, Claredon, Oxford.

Cheung, C. M. K., \& Lee, M. K. O. (2010). A theoretical model of intentional social action in online social network. Decision Support Syst, 49(1), 24-30. http://dx.doi.org/10.1016/j.dss.2009.12.006

Clarkson, M. B. E. (1994). A Risk Based Model of Stakeholder Theory. Proceedings of the Second Toronto Conference on Stakeholder Theory, Centre for Corporate Social Performance \& Ethics University of Toronto, Toronto.

Clarke, T. (2007). International Corporate Governance: A Comparative Approach, New York: Routledge. http://dx.doi.org/10.4324/9780203300725

Coyle-Shapiro, J., \& Shore, L. (2007). The employee-organization relationship: Where do we go from here? Human Resource Management Review, 17(2), 166-179. http://dx.doi.org/10.1016/j.hrmr.2007.03.008

Creswell, J. W. (2002). Educational research: Planning, conducting, and evaluating quantitative. Prentice Hall.

Fichtner, F., Baldi, G., Bremus, F., Brenke, K., Dreger, C., Engerer, H., \& Zaklan, A. (2015). Upswing in a subdued global economy: DIW economic outlook. DIW Economic Bulletin, 5(11), 151-157.

Freeman, R. E. (1999). Divergent stakeholder theory. Academy of management review, 24(2), 233-236. http://dx.doi.org/10.5465/AMR.1999.1893933

Fronell, C., \& Lacker, D. F. (1981) Evaluation structural equation models with unobserved variables and measurement error. J. Mark Res, 18(10), 39-50. http://dx.doi.org/10.2307/3151312

Fuentes-García, F, J., Núñez-Tabales, J, M., \&Veroz-Herradón, R. (2008). Applicability of corporate social responsibility to human resources management: Perspective from Spain. Journal of Business Ethics, 82, 27-44. http://dx.doi.org/10.1007/s10551-007-9560-8

Gouldner, A. (1960). The norm of reciprocity. American Sociological Review, 25(2), 161-178. http://dx.doi.org/10.2307/2092623

Hair, J. F., Black, W. C. , Babin, B. J., \& Anderson, R. E. (2010). Multivariate data analysis. Prentice-Hall, Upper Saddle River, NJ.

Hulin, C. L, Roznowski, M., \& Hachiya, D. (1985). Alternative opportunities and withdrawal decisions: Empirical and theoretical discrepancies and an integration, Psychological Bulletin, 97, 233-250. http://dx.doi.org/10.1037/0033-2909.97.2.233 
Inyang, B. J., Awa, H. O., \& Enuoh, R. O. (2011). CSR-HRM nexus: Defining the role engagement of the human resources professional. International Journal of Business and Social Sciences, 2(5), 118-126.

Kiyak, A., Namazi, K., \& Kahana, E. (1997). Job commitment and turnover among women working in facilities serving older persons. Research on Aging, 19, 223-246. http://dx.doi.org/10.1177/0164027597192004

Kucukusta, D., Mak, A., \& Chan, X. (2013). Corporate social responsibility practices in four and five-star hotels: Perspectives from Hong Kong visitors. International Journal of Hospitality Management, 34(0), 19-30. http://dx.doi.org/10.1016/j.ijhm.2013.01.010

Lepoutre, J., \& Heena, A. (2006). Investigating the impact of firm size on small business social responsibility: A critical review. Journal of Business Ethics, 67(3), 257-273. http://dx.doi.org/10.1007/s10551-006-9183-5

Locke, E. A. (1976). The nature and causes of job satisfaction. Handbook of industrial and organizational psychology, 1, 1297-1343.

Lockett, A., Moon, J., \& Visser, W. (2006). Corporate social responsibility in management research: Focus, nature, salience and sources of influence. Journal of Management Studies, 43(1), 115-136. http://dx.doi.org/10.1111/j.1467-6486.2006.00585.x

Lozano, J. M., \& Prandi, M. (2005). Corporate social responsibility and human rights in Mullerat, Ramon (Ed.), Corporate Social Responsibility, The Corporate Governance of the 21 st century (pp. 183-204). The Hague: Kluwer Law International.

Mobley, W. H. (1977). Intermediate linkages in the relationship between job satisfaction and employee turnover. Journal of Applied Psychology, 62, 237-240. http://dx.doi.org/10.1037/0021-9010.62.2.237

Mor Barak, M., Nissly, J., \& Levin, A. (2001). Antecedents to retention and turnover among child welfare, social work, and other human service employees: What can we learn from past research? A review and met analysis. Social Service Review, 75, 625-661. http://dx.doi.org/10.1086/323166

Morrow, P. C. (2010). Managing organizational commitment: Insights from longitudinal research. Journal of Vocational Behaviour, 79(1), 18-35. http://dx.doi.org/10.1016/j.jvb.2010.12.008

Muchinsky, P. M., \& Morrow, P. C. (1980). A multidisciplinary model of voluntary employee turnover. Journal of Vocational Behavior, 17, 263-290. http://dx.doi.org/10.1016/0001-8791(80)90022-6

O'Reilly, C. A., \& Chatman, J. (1986). Organizational commitment and psychological attachment: The effects of compliance, identification, and internalization on prosocial $\begin{array}{lllll}\text { behavior. Journal of applied } & 492 .\end{array}$ http://dx.doi.org/10.1037/0021-9010.71.3.492 
Organ, D. W. (1988). Organizational citizenship behavior: The good soldier syndrome. Lexington Books/DC Heath and Com.

Price, J. (1977). The study of turnover. Ames, IA: Iowa State University Press.

Price, J., \& C. Mueller (1986). Absenteeism and turnover among hospital employees. Greenwich, CT: JAI Press.

Rahim, A. R., Jalaludin, F. W., \& Tajuddin, K. (2011). The importance of CSR on consumer behaviour in Malaysia. Asian Academy of Management Journal, 16(1), 119-139.

Rupp, D., Gananpathy, J., Aguilera, R., \& Williams, C. (2006). Employee reactions to corporate social responsibility: An organizational justice framework. Journal of Organizational Behavior, 27(4), 537-543. http://dx.doi.org/10.1002/job.380

Sang, S., Lee, L. D., \& Lee, J. (2010). E-government: people, process, and policy (pp. 138-157). Bingley: Emerald Group Publishing Limited. http://dx.doi.org/10.1108/17506161011047370

Thauer, C. R. (2013). Goodness Comes From Within: Intra-Organizational Dynamics of Corporate Social Responsibility. Business \& Society, 0007650313475770.

Turker, D. (2009). Measuring corporate social responsibility: A scale development study. Journal of Business Ethics, 85, 411-427. http://dx.doi.org/10.1007/s10551-008-9780-6

Werther, W. B., \& Chandler, D. (2006). Responsibility: Stakeholders in a Global Environment (Sage Publications, USA).

Wheeler, D., \& Sillanpaa, M. (1997). The Stakeholder Corporation: A Blueprint for Maximizing Stakeholder Value (Pitman, London).

Whitener, E. M. (2001). 'Do "high-commitment" human resource practices affect employee commitment? A cross-level analysis using hierarchical linear modelling'. Journal of Management, 27(5), 515-535. http://dx.doi.org/10.1177/014920630102700502

Williams, L. J., \& Hazer, J. T. (1986). Antecedents and consequences of satisfaction and commitment in turnover models: A reanalysis using latent variable structural equation $\begin{array}{lllll}\text { methods. Journal of applied } & 219 .\end{array}$ http://dx.doi.org/10.1037/0021-9010.71.2.219

Verdeyen, V., Put, J., \& van Buggenhout, B. (2004). A social stakeholder model. International Journal of Social Welfare, $\quad$ 325-331. http://dx.doi.org/10.1111/j.1468-2397.2004.00328.x

Vives, A. (2006). Social and environmental responsibility in small and medium enterprises in Latin America. The Journal of Corporate Citizenship, 21, 39-50. http://dx.doi.org/10.9774/GLEAF.4700.2006.sp.00006 
Glossary

CSR: Corporate Social Responsibility

SMEs: Small Medium Sized Enterprises.

\section{Copyright Disclaimer}

Copyright reserved by the author(s).

This article is an open-access article distributed under the terms and conditions of the Creative Commons Attribution license (http://creativecommons.org/licenses/by/3.0/). 